\title{
Improving Reading Comprehension through STAD of the Eighth Grade Students of SMP Kalam Kudus Bali
}

\author{
I Gusti Made Mas Sika Antari ${ }^{1}$, I Wayan Pastika ${ }^{2}$, I Gusti Ayu Gde Sosiowati ${ }^{3}$ \\ Program Magister (S-2) Ilmu Linguistik, Fakultas Ilmu Budaya, Universitas Udayana \\ e-mail: gekantari03@gmail.com ${ }^{1}$,wayanpastika@unud.ac.id ${ }^{2}$, sosiowati@yahoo.com³
}

\begin{abstract}
This study aimed to find out whether or not reading comprehension of the eighth grade students of SMP Kalam Kudus Bali in academic year 2019/2020 can be improved through STAD. The subject of this study was the students of the eighth grade especially VII B class. This research focused on figuring out the efficacy of STAD in improving reading comprehension, changing learning habit and to find out the factors which influenced the improvement of reading comprehension. The data was collected from the tests and questionnaire. The present study made use Classroom Action Research (CAR) with qualitative and quantitative data. The result of the pretest showed that the ability of the subjects still low and need to be improved. After the implementation of STAD in teaching learning process, the mean score of the subjects was increased and it meant that this technique was successful to improve not only their ability but also it could change their learning habit. It could be seen from the mean score of the pre-test, post-test 1 and post-test 2 was 69.67 , 77.29 and 89.19 .
\end{abstract}

Keywords: teaching reading comprehension; STAD; learning habit; factors in reading comprehension.

\section{Introduction}

Reading is one of the important skills in learning English that should be mastered by the students. It is a process of acquiring information which is delivered by the writer in the form of written text. The students' comprehension can be improved through reading and also their critical thinking. Linse and Nunan (2005:71) state reading comprehension refers to reading for meaning, understanding and entertainment. In reading the readers not only read the text but they also should try to comprehend the meaning of the text to get the information that they want. In teaching learning process, it is very important to implement appropriate technique. STAD is one of the cooperative learning which can be implement to solve this problem because the students can work together in group with different levels and ability.

These research questions are constructed to give a scientific direction and find scientific answers; the research questions are as follows:

1) How effective is STAD in improving reading comprehension of the subjects under study?

2) How effective is STAD in changing the learning habit of the subjects under study?

3) What are the factors which influence in reading comprehension of the subjects under study?

\section{Theoretical Framework}

There are three kinds of theoretical framework were chosen such as: theory of cooperative learning, theory of teaching reading comprehension, theory of STAD and theory of learning habit in reading 
comprehension.

\section{A. Cooperative Language Learning Theory}

Cooperative learning is well-known as a model of instruction which brings the teaching learning process into a different perspective. On the other hand, Oxford in Brown (2001:47) argues that cooperative learning does not imply collaboration. To be sure, in a cooperative classroom the students and teachers work together to pursue goals and objectives. However, cooperative learning is more structured, more prescriptive to teachers about classroom techniques, more directives to students about how to work together in groups than collaborative learning. In cooperative learning models, a group learning activity is dependent on the socially structured exchange of information between students. In collaborative learning, the students engages with more capabilities than others who provide assistanceand guidance.

\section{B. STAD Theory}

Kagan and Kagan (2009:17.20) STAD is an extremely well- researched, effective approach to mastery of basic facts and information. The use of STAD includes enduring teams (usually lasting about six weeks) and an improvement point scoring system, which provides high motivation for students across the range of ability levels. STAD is made up of five interlocking components:

1. Class presentation,

2. Teams,

3. Quizzes,

4. Individual improvement scores, and

5. Team recognition.

\section{Teaching Reading Comprehension Theory}

Creating the conditions for learning to read is the important part that the teacher should pay attention. According to Johnson (2008:11) there were some kinds of conditions that can affect the students such as: help children fall in love with books, create a space every day for sustained, silent reading, allow children to make choices about their reading material, connect reading pleasure to reading practice, keep your reading program simple, keep instruction simple, make reading like real life, etc.

\section{Method}

The research design which was used in this study was classroom action research. According to Ary et al. (2010:514), action research is the process to improve education by incorporating changes and involves educators working together improve their own practices. In this classroom action study, the teaching learning process was divided into some cycles where each cycle consisted of two sessions. Each cycle consisted of four interrelated activities such as: planning, action, observation, and reflection. The data collection was conducted through interview, some tests, questionnaire and documentation. The presentation of the data analysis in informal form is presented in the form of narration which is explain about the improvement of the subjects' in reading comprehension by applying STAD and how subjects' learning habit develop in reading comprehension and formally the data analysis is offered in the form of graphs which is explain about the percentage of subjects' improvement in reading comprehension. 


\section{Results and Discussion}

\section{A. The Efficacy of STAD in Improving Reading Comprehension of the Subjects under Study}

To know the efficacy of STAD in improving reading comprehension in the present study, the researcher was administered a pre-test and post-tests which were in the form of short-answer task. In this tests, the subjects have to read texts clearly then answer the given questions. The criteria of the assessment was included the correct answer and correct grammar. When the researcher applied STAD technique in teaching learning process, the subjects could work together in group to share their opinion each other, however, their critical thinking also can be improved through this cooperative learning.

Based on the result of research, it show that the mean score of the pre-test was 69.67 before applying STAD technique. It happened because the subjects did not comprehend the whole text when they answered the questions. After the STAD applied, the mean score of the post-test 1 was 77.29. It could be improved because the subjects have been learning in group with different levels of the students. They did not only share opinion but, they also can compete to each other. On the other hand, the mean score of the post-test 2 was 89.19. It can be categorized as successful because most of the subjects' ability in reading comprehension could be improved by applying STAD technique. It also made the teaching learning process more active.

\section{B. The Efficacy of STAD in Changing Learning Habit of the Subjects under Study}

The learning habit of the subjects under study was also important to be assessed. Mostly, the subjects liked the instant way to get the answer from what they want to find out. It also happened here, the subjects' learning habit in reading comprehension were the one that need to be improved. To know about their learning habit, they had to fill the learning habit character as an instrument given to the subjects of the study in every teaching learning process. This instrument was constructed in the form of checklist consisting of five elements; they are being discipline, honest, cooperative, respect and creative.

The results in pre-cycle showed that being disciplined was $5.56 \%$, being honest $12.50 \%$, being cooperative $6.94 \%$, being respected $9.72 \%$ and being creative $25.00 \%$. In cycle I, there was an improvement, being disciplined $54.17 \%$, being honest $44.44 \%$, being cooperative $70.83 \%$, being respected $20.83 \%$ and being creative $69.44 \%$. Meanwhile, in cycle II, the subjects' learning habit more improved. In being disciplined $69.44 \%$, being honest $55.56 \%$, being cooperative $72.22 \%$, being respected $22.22 \%$ and being creative $75.00 \%$. It meant that STAD is efficient to be applied in changing learning habit based on their problem.

\section{The Factors which Influence the Improvement Subjects' Reading Comprehension}

The successful of this research also supporting by knowing what was the factors which is influenced in subjects' reading comprehension. The factors divided into two; internal and external factors. According to Kahayanto (2005:13) internal factor is usually known as personal factor, because the factor has existed inside the reader. This factors were motivation and interest. The second was external factors. They were reading material, teacher of reading and questioning strategies. According to Brown (2001:169) the most important key to create an interactive learning is the initiation of interaction from the teacher by using question. Based on the result from the questionnaire which was conducted to the subjects, it revealed that most of the subjects choose 'agree' as the higher answer. They admitted the factors which influence the improvement of learning reading comprehension were from internal and external factors. 


\section{Conclusion}

The present classroom action research was finally stopped because it had already achieved the success indicators which have already been set up in chapter III. The progressing results of tests showed that the mean score of the subjects significantly increased. It clearly clarified that the implementation of STAD in improving and changing subjects' learning habit in reading comprehension brought a more interesting teaching learning atmosphere it was shown by the result of the questionnaire. As a results, it affected the improvement of the subjects' achievement in reading comprehension while they work in a group and individually. Their achievement was from 'insufficient' to 'good'. The improvement was not only come from their mean score but also from their ability to comprehend and answer a given text from the teacher.

\section{References}

Alderson, J. C. (2000). Assessing Reading. Cambridge: University Press.

Arends, R. I. and Kilcher, A. (2010). Teaching for Student Learning Becoming an Accomplished Teacher. Oxon: Routledge.

Ary, D., Jacobs, L. C., Sorensen, C., and Razavieh, A. (2010). Introduction to Research in Education (8th ed.). California: Wadsworth, Cengage Learning.

Boardman, A. (2007). Teaching Reading Comprehension to students with learning difficulties. New York: The Guilford Press.

Brasell, D. and Rasinski, T. (2008). Comprehension that Works Taking Students Beyond Ordinary. Huntington Beach: Shell Education. Brown, H. D (2004). Language Assessment Principles and Classroom Practices. New York: Pearson Education.

Burns, A. (2010). Doing Action Research in English Language Teaching a Guide for Practitioners. New York: Routledge Taylor and Francis Group.

Camille, B. (2008). Reading Comprehension Strategies and Independent Learners. New York: The Guilford Press.

Caldwell, J. S. (2008). Reading Assessment a Primer for Teachers and Coaches. Second Edition. New York: The Guilford

Press. Cohen, L., Lawrence M., and Keith M. (2007). Research Methods in Education $6{ }^{\text {th }}$ Edition. Abingdon: Routlegde.

Dawson C. (2007) Practical Research Methods. New York: How to Books Ltd.

Goodnough, K. (2011). Taking Action in Science Classrooms through Collaborative Action Research. Rotterdam: Sense Publishers.

Grabe, W. (2009). Reading in a Second Language Moving from Theory to Practice. Cambridge: University Press.

Jolliffee, W. (2007). Cooperative Learning in the Classroom Putting It into Practice. London: Paul Chapman Publishing.

Kagan, M. and Kagan, S. (2009). Kagan Cooperative Learning. San Clemente: Kagan Publishing.

Kahayanto.E. (2005). a Comparative Study on Students `Achievements in Reading I of the Education Study Program of Palangkaraya University Who Entered through PSB and SPMB in Academic Year 2003/2004. Unpublished Thesis. : The faculty of Teacher and Training and Education University of Palangkaraya.

Klinger, J, K., Vaugh, S., and Boardman, A. (2007). Teaching Reading Comprehension to Students with Learning Difficulties. New York: The Guilford Press.

Lems, K., Miller, L. D., Soro, T. M. (2010). Teaching Reading to English Language Learners. London: The Guilford Press.

Linse, C. T. and Nunan, D. (2005). English Language Teaching Practical Young Learners. New York: McGraw-Hill ESL/ELT.

McNiff, J. and Whitehead, J. (2006). All You Need to Know About Action Research. London: ECIY.

N'Namdi, K. A. (2005). Guide to Teaching Reading at the Primary School Level. France: United National Education.

Pang, E. S., Muaka, A., Bernhard, E. B., Kamil, M. C. (2003). Teaching Reading. Brussels: IAE.

Richards, J.C. and Rodgers, T.S. (2001). Approaches and Methods in Language Teaching. Second Edition. Cambridge: University Press.

Rifky, H. (2013). Implementation of Cooperative Learning Method in Teaching Reading Comprehension. Journal of English and Education. 1. (2): 60.

Sophia, F. (2013). The Implementation of Cooperative Learning: Student Teams-Achievement Divisions Technique in Teaching Reading Comprehension. Journal of English and Education. 1. (2): 83-86.

Smith, F. (2004). Understanding Reading a Psycholinguistics Analysis of Reading and Learning to Read. Mahwah, NJ: Lawrence Erlbaum. 
Snow, C. E. (2002). Reading for Understanding toward a Research and Development Program in Reading Comprehension. Pittsburgh: Rand.

Wynne, S. (2008). Reading Instruction Competence Assessment. Boston: XAmonline.com. 